\title{
Antennal sensory structures in water bugs of Nepoidea (Insecta: Hemiptera: Nepomorpha), their morphology and function
}

\author{
Agnieszka Nowińska ${ }^{1}$ (D) Jolanta Brożek ${ }^{1}$
}

Received: 2 January 2019 / Accepted: 30 April 2019 / Published online: 11 May 2019

(c) The Author(s) 2019

\begin{abstract}
The Nepoidea superfamily belongs to the water bugs' infraorder (Nepomorpha) and consists of two families-Belostomatidae and Nepidae. Species from those families are the largest of all nepomorphans and are considered to be top predators in aquatic ecosystems. A characteristic feature of the group is the existence of short antennae concealed in grooves behind the eyes, which is an adaptation to the water habitat. The antennae bear many types of sensillar structures, which receive signals from the environment. Among such structures, mechanosensilla were of the greatest diversity. The antennal sensilla of species from both families were examined under the scanning electron microscope. 11 essential morphological types of sensilla were distinguished, including 5 new mechanosensilla types (sensilla paddle-like, cone-like, squamiformia, brush-like and club-like). Basal types of mechanosensilla such as trichodea, chaetica, basiconica (subtype 1) and campaniformia occur in Nepoidea and other Heteroptera. In some representatives of both families, sensilla paddle-like and sensilla basiconica type 1 were observed. Moreover, sensilla chaetica and cone-like were found in some species of Belostomatidae, whereas in Nepidae sensilla squamiformia, brush-like and club-like were observed. Apart from mechanosensilla, one type of thermohygrosensilla (ampullacea) and two different shaped olfactory sensilla basiconica (subtypes 2,3) and coeloconica (subtypes $1,2,3)$ were found. It could indicate sensilla use in the identification of the water reservoirs and locating prey.
\end{abstract}

Keywords Antennal sensilla $\cdot$ Morphology $\cdot$ Function $\cdot$ Water bugs

\section{Introduction}

Aquatic heteropterans (Nepomorpha) play an important role in organizing the invertebrate community structure in natural water pools (Runck and Blinn 1994; Blaustein 1998). The most significant are the largest species (e.g., Belostomatidae, Nepidae, Notonectidae). They are considered to be the top insect predators in those aquatic ecosystems (Waters 1977; Runck and Blinn 1990). Nepomorphan species are distributed worldwide, although the greatest diversity is shown in the tropics (Schuh and Slater 1995). They prefer still water habitats, such as shallow, muddy pools or slow-moving streams and most of them are sedentary hunters (Menke 1979). Infraorder Nepomorpha consists of 11 families (Chen et al. 2005) grouped in seven superfamilies (Hebsgaard et al.

Agnieszka Nowińska

agnieszka.nowinska@us.edu.pl

1 Department of Zoology, Faculty of Biology and Environmental Protection, University of Silesia, Bankowa 9, 40-007 Katowice, Poland
2004; Brożek 2014). The first taxon, the Nepoidea superfamily, is placed as the basal branch of the Nepomorpha phylogenetic tree and consists of two families: Belostomatidae and Nepidae (Popov 1971; Hebsgaard et al. 2004). As a rule, the basic taxon represents the most plesiomorphic condition, so some of the characters can be considered as basic original morphological structures in Nepomorpha. The morphology of Nepomorpha clearly expresses adaptive traits and the body composition is different in every family or even subfamily. In Belostomatidae, the body shape is more or less oval, in Ranatrinae it is elongated and baton-like, whereas in most Nepinae it is flat and oblong-oval (Popov 1971). The size of their body varies from small to large. In belostomatid species, it is 9-110 mm long and in nepid species it is 15-45 mm. The antennae of Nepoidea are short and either concealed in grooves behind the eyes (Belostomatidae), or lie flat under the head (Nepidae), usually with finger-like processes on one or two segments. There are four antennomeres in Belostomatidae and three antennomeres in Nepidae (Schuh and Slater 1995; Chen et al. 2005). Generally, insects rely heavily on the perception of chemical stimuli 
for foraging, as well as intraspecific and interspecific communication (Cossé et al. 1995; Attygalle et al. 1996; Nishida et al. 1996; Yarden et al. 1996; Paulmier et al. 1999; Drijfhout and Groot 2001). The most important receptor organs are antennal sensilla, considered to be the primary insect peripheral olfactory system for most insects (Chapman 1998; Keil 1999; de Bruyne and Baker 2008). Those are structures that receive signals from the environment. Different types of sensilla were described according to the type of signal. They are classified into four main groups-olfactory sensilla, gustatory sensilla, mechanosensilla and hygro- and thermosensilla. Moreover, sensilla are classified into more groups, according to their cuticular structure (Slifer 1970; Altner and Prillinger 1980; Hallberg and Hansson 1999).

Generally, insect antennae possess a considerable diversity and high density of sensilla with tactile, olfactory or gustatory function (Inouchi et al. 1987; Isidoro et al. 1996; Kim and Leal 2000). The incidence, density and distribution of different types of sensilla differ among species and, to a variable extent, between sexes within a species (Esslen and Kaissling 1976; Ågren 1978; Martini 1986; Jourdan et al. 1995; van Baaren et al. 1999). These differences in sensillar equipment are probably related to differences in taxonomy, ecology, mating system and other behavioral aspects of the species or their sexes (Wcislo 1995; Merivee et al. 1999). In nepomorphan species, because of their watery life, sexual behavior is realized through the signal/stridulatory system (Jansson 1973). So what type of sensilla are present in the antenna of the water bugs? So far, in the whole Nepomorpha, only labial sensilla type and function have been described by Brożek (2013). The sensory organs are common in the insects and are located in the antennae, mouthparts (labium, labial and maxillary palps and proboscis), genitalia, legs and wings (Peregrine 1972; Backus 1985; Brożek and Bourgoin 2013; Brożek 2013; Brożek and Zettel 2014; de Bruyne and Baker 2008; Guerenstein and Hildebrand 2008; Nichols and Vogt 2008; Devetak et al. 2004; Kanturski et al. 2016; Wang and Dai 2017) as well as on other parts of the body (Catalá 1996; Chapman 1998).

In this study, we investigate the sensillar morphology and distribution on the antennae of nepid and belostomatid species and define the role of antennal sensilla for these aquatic insects. The studied species probably differs considerably with regard to the numbers and shape of the chemical and mechanical sensilla that are important for the sensory system. We expect differences in the Nepoidea's sensory system because sensilla are important for their various biological/ ecological behavior. Also, sensilla can be different in particular taxa of Nepoidea and other heteropteran species.

\section{Materials and methods}

The morphology and distribution of sensilla of two subfamilies of Nepoidea were examined. We did not focus observation on sexual dimorphism.

This study is based on the dry material of seven genera from two families. All material was cleaned, drained in ethanol, coated with a gold film and photographed using a Hitachi scanning electron microscope and Phenom XL scanning electron microscope in the scanning microscopy laboratory of the Faculty of Biology and Environmental Protection of Silesian University in Katowice. The species that were examined were obtained from the Natural History Museum in Vienna, the Moravian Museum in Brno, the National Museum in Prague and the Zoology Museum in Copenhagen. Designation of the species after Štys and Jansson (1988) and Nieser et al. (2010).

Examined species:

Belostomatidae: Belostomatinae: Belostoma elegans Mayr, 1871.

Diplonychus annulatus Fabricius, 1781.

Hydrocyrius colombiae Spinola, 1852.

Lethocerinae: Lethocerus indicus Lepeletier \& Serville, 1825.

Lethocerus patruelis Stål 1854.

Nepidae: Nepinae: Nepa cinerea Linnaeus, 1758.

Laccotrephes fabricii Stål 1868.

Laccotrephes fuscus Linnaeus, 1758.

Ranatrinae: Ranatra grandocula Bergroth, 1893.

Ranatra linearis Linnaeus, 1758.

Ranatra unicolor Scott, 1874.

\section{Results}

According to the role they play, sensilla have different shapes and different internal structures. Therefore, they are being grouped in types. The characteristic features are the presence of pores, surface and shape of the sensillum and socket type. Generally, the sensilla arise from two types of cuticular sockets. Flexible sockets have a thin cuticular membrane, which is continuous with the general body cuticle and the hair. It provides greater mobility at the base of the sensilla (mechanosensilla). Another type (inflexible socket) is when sensilla arise from a cuticle without a membrane (chemosensilla and thermo-hygrosensilla). The characteristic morphological features of the antennal sensilla and their classification are based on the papers of Slifer (1970), McIver (1975), Altner and Prillinger (1980), Hallberg and Hansson (1999), Shields (2010) and Nowińska and Brożek (2017). 
During our studies, different shapes of antennae were observed and the basal terminology for description was used after Popov (1971), Schuh and Slater (1995) and Chen et al. (2005). The terms "dorsal" and "ventral" consistently refer to the short body axis (orientation toward eyes).

Antennae of Belostomatidae consist of four antennomeres and are provided with a singular process ( $\mathrm{pr}$ ) on the second and third antennomeres. The length of these processes is $100 \mu \mathrm{m}-2.6 \mathrm{~mm}$ (Table 1) and these elements increase the lateral surface of the antennae. In Belostoma elegans, Laccotrephes and Ranatra, the last antennomere is the longest. In Diplonychus annulatus, the processes on the second and third antennomere are small and easy to distinguish. In studied species of Hydrocyrius and Lethocerus, the last antennomere resembles the processes on the second and third antennomere. Furthermore, in the species of Lethocerus, we observed an additional short process (prs) (around $0.5 \mathrm{~mm}$ ) on the last antennomere, which has not been described before. In species from Nepidae, antennae also bear singular processes despite having only three antennomeres. The process is located on the second antennomere and in different species $130 \mu \mathrm{m}-1.7 \mathrm{~mm}$ long (Table 1). In Nepa cinerea, the process extends along the main axis of the antenna. However, in the studied species of Laccotrephes and Ranatra, the last antennomere tends to bend toward the process on the second antennomere. That process extends across the main axis of the antenna and its length is similar to the length of the antennomere. Only the antennae of Ranatra grandocula show some differences. The third antennomere is the longest, and the process on the second antennomere is very short. In both families, the antennae have a wider lateral surface for a bigger number of sensilla without the need of lengthening

Table 1 Length of the antennomeres and length of the processes within the species (data were obtained based on the measurements of several specimens of particular taxa)

\begin{tabular}{|c|c|c|c|c|c|c|}
\hline \multirow[t]{2}{*}{ Family } & \multirow[t]{2}{*}{ Subfamily } & \multirow[t]{2}{*}{ Species/specimens } & \multicolumn{4}{|c|}{ Length of the antennomeres and length of the processes } \\
\hline & & & Antennomere I & Antennomere II & Antennomere III & Antennomere IV \\
\hline \multirow[t]{5}{*}{ Belostomatidae } & \multirow[t]{3}{*}{ Belostomatinae } & $\begin{array}{l}\text { Belostoma elegans } \\
\text { (Fig. 4) } \\
1 \text { specimen }\end{array}$ & $400 \mu \mathrm{m}$ & $\begin{array}{l}150 \mu \mathrm{m}+700 \mu \mathrm{m} \\
\text { process }\end{array}$ & $\begin{array}{l}100 \mu \mathrm{m}+700 \mu \mathrm{m} \\
\text { process }\end{array}$ & $600 \mu \mathrm{m}$ \\
\hline & & $\begin{array}{l}\text { Diplonychus annula- } \\
\text { tus (Fig. 4) } \\
1 \text { specimen }\end{array}$ & $350 \mu \mathrm{m}$ & $\begin{array}{l}150 \mu \mathrm{m}+100 \mu \mathrm{m} \\
\text { process }\end{array}$ & $\begin{array}{l}200 \mu \mathrm{m}+100 \mu \mathrm{m} \\
\text { process }\end{array}$ & $180 \mu \mathrm{m}$ \\
\hline & & $\begin{array}{l}\text { Hydrocyrius colom- } \\
\text { biae (Fig. 5) } \\
2 \text { specimens }\end{array}$ & $1000 \mu \mathrm{m}$ & $\begin{array}{l}500 \mu \mathrm{m}+2200 \mu \mathrm{m} \\
\text { process }\end{array}$ & $\begin{array}{l}500 \mu \mathrm{m}+2200 \mu \mathrm{m} \\
\text { process }\end{array}$ & $2000 \mu \mathrm{m}$ \\
\hline & \multirow[t]{2}{*}{ Lethocerinae } & $\begin{array}{l}\text { Lethocerus indicus } \\
\text { (Fig. 6) } \\
1 \text { specimen }\end{array}$ & $1000 \mu \mathrm{m}$ & $\begin{array}{l}800 \mu \mathrm{m}+2600 \mu \mathrm{m} \\
\text { process }\end{array}$ & $\begin{array}{l}450 \mu \mathrm{m}+2000 \mu \mathrm{m} \\
\text { process }\end{array}$ & $\begin{array}{l}1500 \mu \mathrm{m}+300 \mu \mathrm{m} \\
\text { process }\end{array}$ \\
\hline & & $\begin{array}{l}\text { Lethocerus patruelis } \\
\text { (Fig. 5) } \\
3 \text { specimens }\end{array}$ & $1000 \mu \mathrm{m}$ & $\begin{array}{l}800 \mu \mathrm{m}+2400 \mu \mathrm{m} \\
\text { process }\end{array}$ & $\begin{array}{l}400 \mu \mathrm{m}+2000 \mu \mathrm{m} \\
\text { process }\end{array}$ & $\begin{array}{l}1000 \mu \mathrm{m}+250 \mu \mathrm{m} \\
\text { process }\end{array}$ \\
\hline \multirow[t]{6}{*}{ Nepidae } & \multirow[t]{3}{*}{ Nepinae } & $\begin{array}{l}\text { Nepa cinerea (Figs. } 7 \text {, } \\
8 \text { ) } \\
5 \text { specimens }\end{array}$ & $220 \mu \mathrm{m}$ & $\begin{array}{l}200 \mu \mathrm{m}+200 \mu \mathrm{m} \\
\text { process }\end{array}$ & $400 \mu \mathrm{m}$ & - \\
\hline & & $\begin{array}{l}\text { Laccotrephes fuscus } \\
\text { (Fig. 9) } \\
1 \text { specimen }\end{array}$ & $350 \mu \mathrm{m}$ & $\begin{array}{l}300 \mu \mathrm{m}+1100 \mu \mathrm{m} \\
\text { process }\end{array}$ & $1200 \mu \mathrm{m}$ & - \\
\hline & & $\begin{array}{l}\text { Laccotrephes fabricii } \\
\text { (Fig. 9) } \\
1 \text { specimen }\end{array}$ & $700 \mu \mathrm{m}$ & $\begin{array}{l}500 \mu \mathrm{m}+1700 \mu \mathrm{m} \\
\text { process }\end{array}$ & $1600 \mu \mathrm{m}$ & - \\
\hline & \multirow[t]{3}{*}{ Ranatrinae } & $\begin{array}{l}\text { Ranatra grandocula } \\
\text { (Fig. 10) } \\
1 \text { specimen }\end{array}$ & $280 \mu \mathrm{m}$ & $\begin{array}{l}290 \mu \mathrm{m}+130 \mu \mathrm{m} \\
\text { process }\end{array}$ & $300 \mu \mathrm{m}$ & - \\
\hline & & $\begin{array}{l}\text { Ranatra linearis } \\
\quad \text { (Fig. 11) } \\
2 \text { specimens }\end{array}$ & $220 \mu \mathrm{m}$ & $\begin{array}{l}200 \mu \mathrm{m}+260 \mu \mathrm{m} \\
\text { process }\end{array}$ & $400 \mu \mathrm{m}$ & - \\
\hline & & $\begin{array}{l}\text { Ranatra unicolor } \\
\text { (Fig. 12) } \\
1 \text { specimen }\end{array}$ & $150 \mu \mathrm{m}$ & $\begin{array}{l}150 \mu \mathrm{m}+150 \mu \mathrm{m} \\
\text { process }\end{array}$ & $300 \mu \mathrm{m}$ & - \\
\hline
\end{tabular}



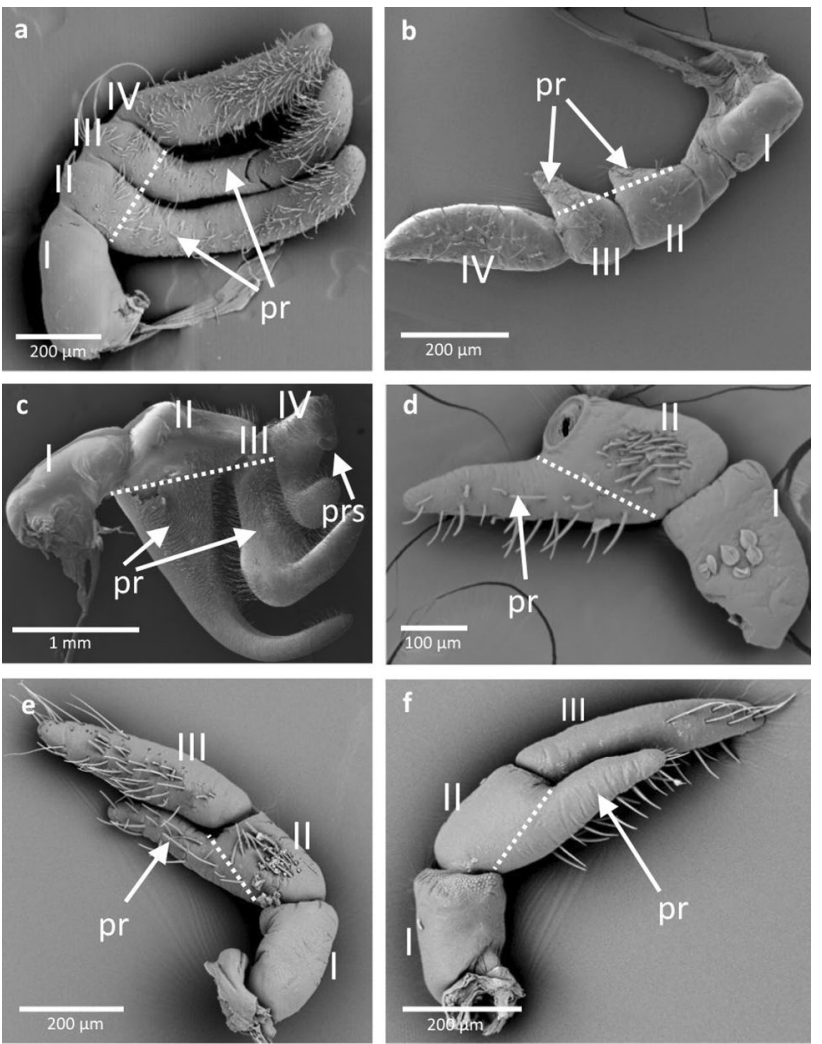

Fig. 1 Shapes of the antennae of examined species. a Belostoma elegans ventral view; b Diplonychus annulatus ventral view; c Lethocerus patruelis ventral view; d, e Nepa cinerea ventral view; f Nepa cinerea dorsal view. $I-I V$ number of antennomeres; $p r$ processes of the antennomeres; prs additional short process; dotted line-supposed boundary between antennomere's surface and process's surface

the antenna itself. This particular shape allows the antennae to remain hidden under the eyes (Figs. 1,2).

Based on the study, 11 types of sensilla were observed and, depending on their morphological characters and function, the following three groups of sensilla have been described (Table 2; Figs. 3, 4, 5, 6, 7, 8, 9, 10, 11, 12).

I. Mechanosensilla (Table 2; Fig. 3). Nine types of sensilla have been classified (S. trichodea, S. chaetica, S. cone-like, S. brush-like, S. campaniformia, S. club-like, S. paddle-like, S. squamiform and S. basiconicum (SB1)) within this group. Three subtypes were distinguished (ST1, ST2, ST3) just within sensilla trichodea:

Sensilla trichodea (ST) - these are hair-like sensilla, varying in length. They are usually thin and taper from base to tip. They arise from flexible sockets and were observed on every antennal segment (Figs. 3, 6c-e, 7b, $8 \mathrm{a}, \mathrm{b}, \mathrm{d}, 9 \mathrm{f})$. Due to differences in surface, shapes and sizes, three subtypes of these sensilla were distinguished.

Sensilla trichodea (ST1) - these are long, thin sensilla, with a smooth surface. They are straight, soft and flexible.
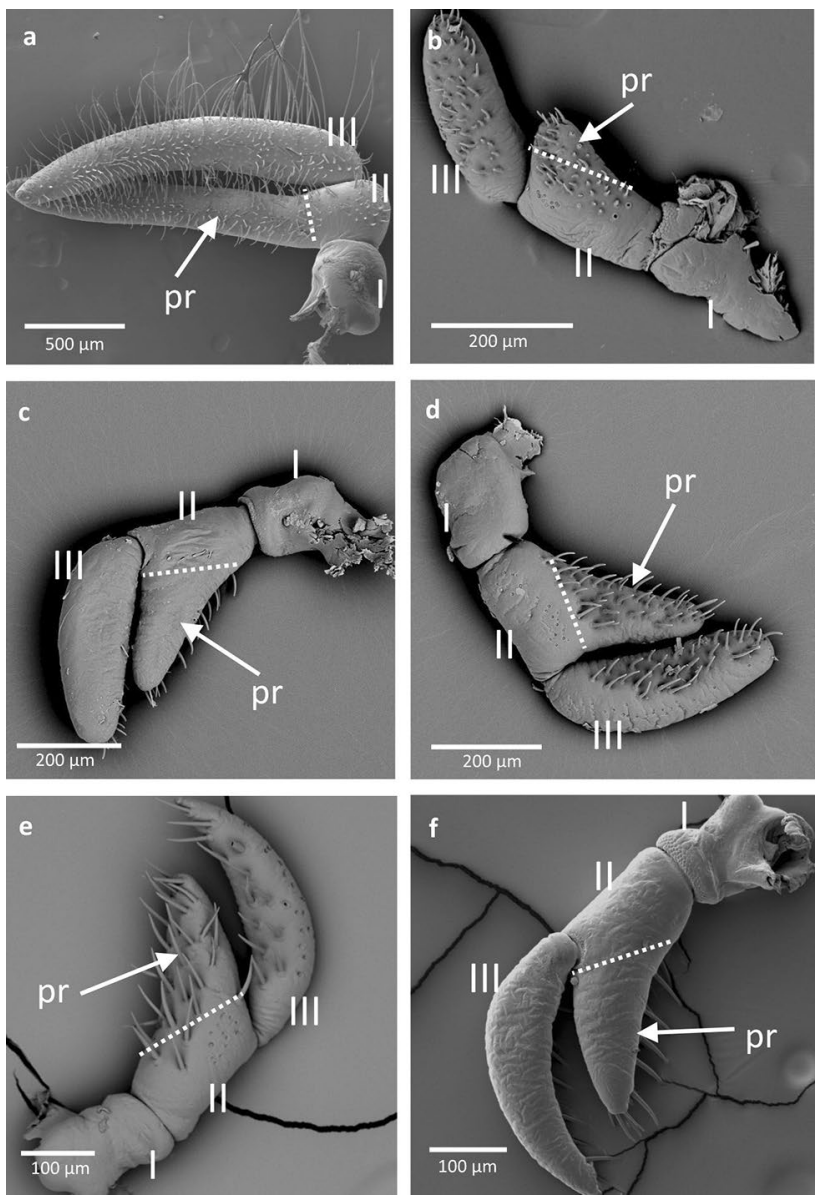

Fig. 2 Shapes of the antennae of the examined species. a Laccotrephes fabricii ventral view; b Ranatra grandocula ventral view; c Ranatra linearis dorsal view; d Ranatra linearis ventral view; e Ranatra unicolor ventral view; f Ranatra linearis dorsal view. I-III number of antennomeres; $p r$ processes of the antennomeres; dotted line-supposed boundary between antennomere's surface and process's surface

They were observed in all the examined species (Figs. 3, $7 \mathrm{~b}, 8 \mathrm{a}, \mathrm{b}, \mathrm{d})$.

Sensilla trichodea (ST2) - these are long, straight or curved at the tip sensilla with a slightly rounded tip and a ribbed surface. They were also found in species of both families (D. annulatus, $H$. colombiae, $L$. indicus, $L$. patruelis, N. cinerea, L. fuscus and L. fabricii) (Figs. 3, 6e, 9f). In L. indicus, they cover most of the anterior surface of the antennae. In other species, they occur more rarely although usually not singularly.

Sensilla trichodea (ST3) - these are long sensilla, flattened through the whole length, ribbed, found only in the L. indicus and patruelis, on the inner edge of the third and fourth antennomere (Fig. 6c, d).

Sensilla chaetica $(\mathrm{SCh})$ - these sensilla are much more rigid than trichoid sensilla. They are long, sharpened at the tip, ribbed and arise from flexible sockets. Sensilla chaetica 
Table 2 Distribution of sensilla in subfamilies

\begin{tabular}{|c|c|c|c|c|c|}
\hline \multirow[t]{2}{*}{ Family } & \multirow[t]{2}{*}{ Subfamily } & \multirow[t]{2}{*}{ Species } & \multicolumn{3}{|l|}{ Type of sensilla present } \\
\hline & & & Mechanosensilla & $\begin{array}{l}\text { Thermo- } \\
\text { hygrosen- } \\
\text { silla }\end{array}$ & Chemosensilla/olfactory \\
\hline \multirow[t]{5}{*}{ Belostomatidae } & \multirow[t]{3}{*}{ Belostomatinae } & Belostoma elegans (Fig. 4) & ST1, SCa, SPL2, SB1 & SA & $\mathrm{SB} 2, \mathrm{SB} 3, \mathrm{SC} 3$ \\
\hline & & Diplonychus annulatus (Fig. 4) & ST1, ST2, SCh, SCa & & $\mathrm{SB} 2, \mathrm{SB} 3, \mathrm{SC} 3$ \\
\hline & & Hydrocyrius colombiae (Fig. 5) & ST1, ST2, SCh, SCa & SA & $\mathrm{SB} 2, \mathrm{SB} 3, \mathrm{SCo} 1 \mathrm{SCo} 2, \mathrm{SCo} 3$ \\
\hline & \multirow[t]{2}{*}{ Lethocerinae } & Lethocerus indicus (Fig. 6) & $\begin{array}{l}\text { ST2, ST3, SCh, SCa, SCoL, } \\
\text { SB1 }\end{array}$ & SA & $\mathrm{SB} 2, \mathrm{SCo} 2$ \\
\hline & & Lethocerus patruelis (Fig. 5) & ST2, SCh, SCa, SPL2 & SA & $\mathrm{SB} 2, \mathrm{SCo} 2$ \\
\hline \multirow[t]{6}{*}{ Nepidae } & \multirow[t]{3}{*}{ Nepinae } & Nepa cinerea (Fig. 7,8) & $\begin{array}{l}\text { ST1, ST2, SSq SBL, SCa,SPL2, } \\
\text { SCIL, SB1 }\end{array}$ & SA & $\mathrm{SB} 2, \mathrm{SB} 3, \mathrm{SC} 33$ \\
\hline & & Laccotrephes fuscus (Fig. 9) & $\mathrm{ST} 2, \mathrm{SCa}, \mathrm{SSq}$ & & $\mathrm{SB} 2, \mathrm{SB} 3, \mathrm{SC} 3$ \\
\hline & & Laccotrephes fabricii (Fig. 9) & ST2, SCa, SPL1 SSq & SA & $\mathrm{SB} 2, \mathrm{SB} 3, \mathrm{SCo} 2, \mathrm{SCo} 3$ \\
\hline & \multirow[t]{3}{*}{ Ranatrinae } & Ranatra grandocula (Fig. 10) & SCIL, SCa & SA & $\mathrm{SB} 2, \mathrm{SB} 3, \mathrm{SCo} 3$ \\
\hline & & Ranatra linearis (Fig. 11) & SPL1, SCa & & $\mathrm{SB} 2, \mathrm{SCo} 2, \mathrm{SCo} 3$ \\
\hline & & Ranatra unicolor (Fig. 12) & SCa, SPL1 & SA & $\mathrm{SB} 2, \mathrm{SCo} 2, \mathrm{SCo} 3$ \\
\hline
\end{tabular}

Fig. 3 Illustration of the three groups of sensilla. $S T 1$ sensilla trichodea subtype $1, S T 2$ sensilla trichodea subtype 2 , ST3 sensilla trichodea subtype 3, SCh sensilla chaetica, $S C O L$ sensilla cone-like, $S B L$ sensilla brush-like, $S C a$ sensilla campaniformia, $S C l L$ sensilla club-like, SPL1 sensilla paddle-like subtype 1, SPL2 sensilla paddle-like subtype 2 , $S S q$ sensilla squamiformia, $S B 1$ sensilla basiconica subtype 1 , $S B 2$ sensilla basiconica subtype 2, SB3 sensilla basiconica subtype 3, SCo1 sensilla coeloconica subtype 1, SCo2 sensilla coeloconica subtype 2, SCo3 sensilla coeloconica subtype 3, $S A$ sensilla ampullacea

\section{MECHANOSENSILLA}
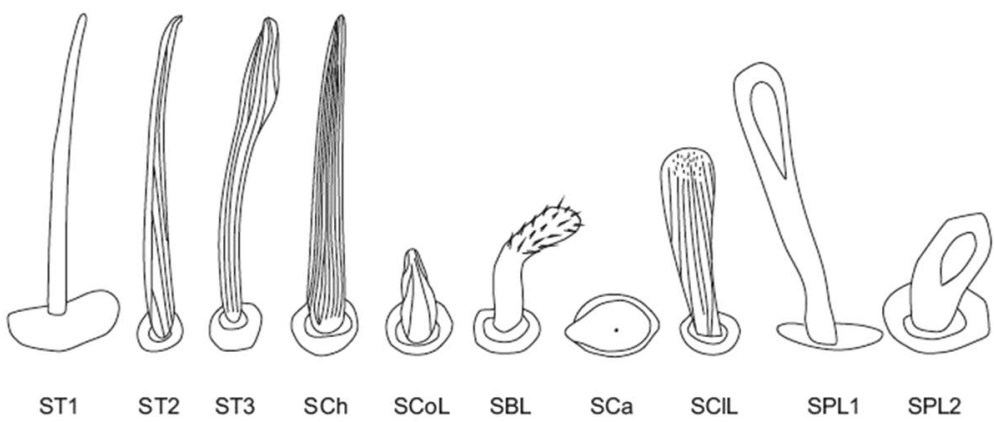

SCIL $\quad$ SPL1 SPL2 $\quad$ SS

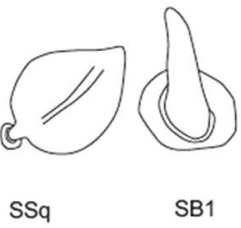

THERMO-HYGROSENSILLUM

\section{CHEMOSENSILLA}
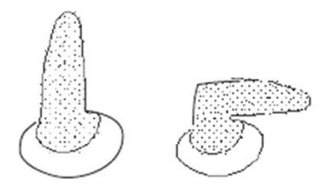

SB3

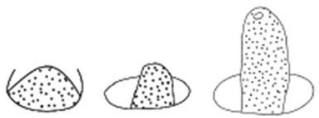

$\mathrm{SC} 1 \quad \mathrm{SC} 02 \quad \mathrm{SC} 03$

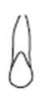

SA are much less common than sensilla trichoidea. They were only observed in the family Belostomatidae (H. colombiae, L. indicus and L. patruelis) (Figs. 3, 4d, 5a).

Cone-like sensilla (SCoL) — these are short, thick sensilla, rounded at the tip, with a ribbed surface, not occurring in groups. Sensilla arise from the flexible sockets. They were found on the dorsal side of antennae in L. indicus (Figs. 3, 6f) and L. patruelis.

Brush-like sensilla (SBL) - these are slightly curved sensillum with the same thickness over the entire length, microtrichia on the top half, a smooth surface and a flexible socket. The sensillum occurs on the last antennomere in $N$. cinerea (Figs. 3, 8d).

Sensilla campaniformia (SCa) - these are flat, oval discs with a single pore observed on their surface. They are inserted in flexible sockets and occur in different places of the antennomere. They are present in most of the examined species (Figs. 3, 4e, 5d, 6a, 7d, 9d).

Club-like sensilla (SCIL) - in this type of sensilla, the base and shaft are more or less of the same width. The tip 

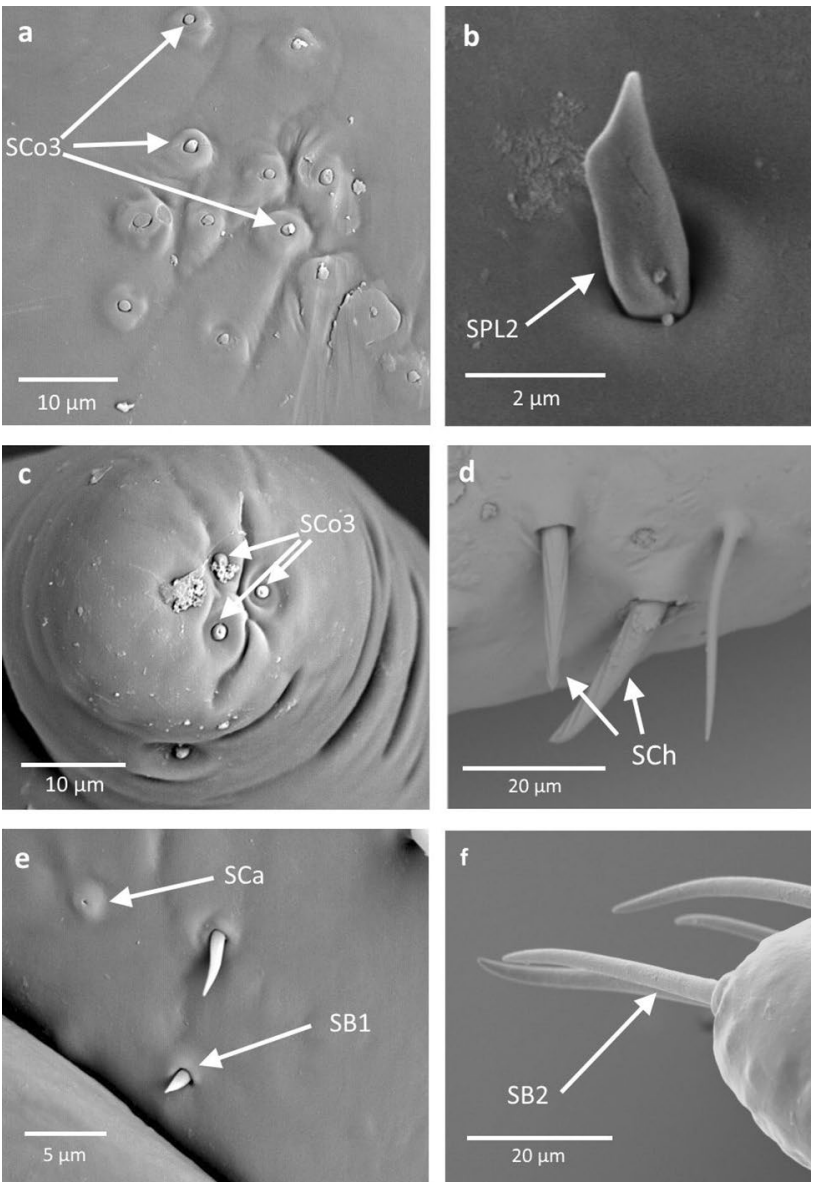

Fig. 4 Distibution of sensilla in Belostoma elegans and Diplonychus annulatus. a-c B. elegans; d-f D. annulatus. SCo3 sensilla coeloconica subtype 3, SPL2 sensilla paddle-like subtype 2, SCh sensilla chaetica, $S C a$ sensilla campaniformia, $S B 1$ sensilla basiconica subtype $1, S B 2$ sensilla basiconica subtype 2

of the sensillum is slightly rounded. The sensillum is ribbed on the whole surface. As all the other mechanosensilla, they arise from flexible sockets. Club-like sensillum was found only in $R$. grandocula and occurs as a single structure on the surface of the first antennomere (Figs. 3, 10b).

Paddle-like sensilla (SPL) - they arise from the socket with a narrow lower part and then gradually widen to a flattened tip (Figs. 3, 4b, 5e, 8a, 9c, 11b, 12d). They have a smooth surface and arise from flexible sockets. Two types of paddle-like sensilla were found. Elongated paddlelike sensilla (SPL1) were observed in the family Nepidae (Figs. 3, 8a, 9c, 11b, 12d), while shortened paddle-like sensilla (SPL2) were observed in both families (B. elegans, $L$. patruelis, L. fabricii, R. linearis, R. unicolor) (Figs. 3, 4b, $5 e)$.

Sensilla squamiformia (SSq) — these are sensilla that vary in shape and size. They are slightly rhombic shaped, resembling a broad leaf. Usually they are smooth, covered by short hairs. They arise from flexible sockets. They were found in
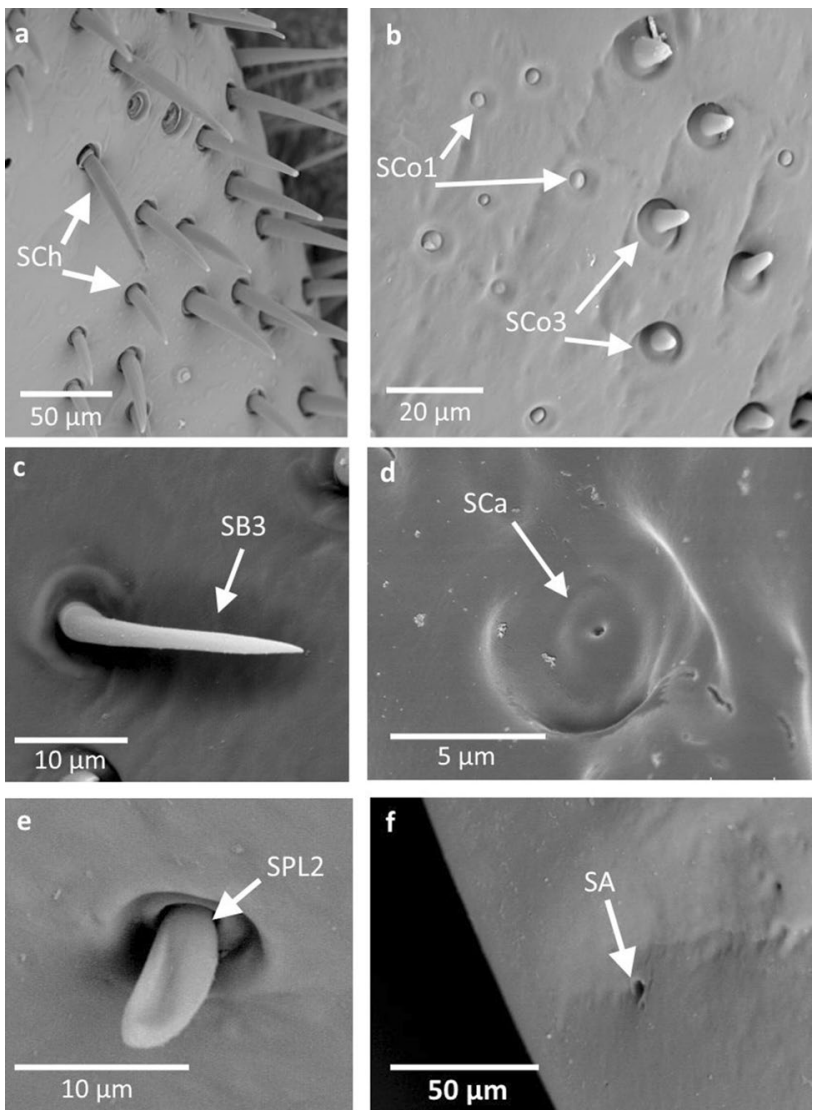

Fig. 5 Distribution of sensilla in Hydrocyrius colombiae and Lethocerus patruelis. a-c $-H$. colombiae, d-f $L$. patruelis. SCh sensilla chaetica, SCo1 sensilla coeloconica subtype 1, SCo3 sensilla coeloconica subtype 3, SB3 sensilla basiconica subtype 3, SCa sensilla campaniformia, SPL2 sensilla paddle-like subtype 2, SA sensilla ampullacea

Nepa and Laccotrephes. Generally, they occur on the first antennomere (Figs. 3, 9a, c).

Sensilla basiconica (SB1) — these are straight cones with a smooth surface and flexible socket. They occur between two antennomeres, as they are believed to play a proprioceptive role (Figs. 3, 4e).

II. Thermo-hygrosensilla- a pit organ belonging to the so-called "peg in pit":

Sensilla ampullacea (SA) - they are characterized by a round external, cuticular opening to the outside, in which no peg is visible because it is set internally at the bottom of a tube. Sensilla ampullacea rise from inflexible sockets. They were found in B. elegans, L. indicus, L. patruelis, $N$. cinerea, $L$. fabricii and $R$. grandocula. These structures were considered to be sensilla, because of their single appearance and no evidence of secretion, which would indicate glandular structures. However, the function should be confirmed with ultrastructural studies (Figs. 3, 5f, 7d, 8b, 9b, 10c, 12a).

III. Chemosensilla-these are sensilla with porous surface, different lengths and shapes. There were two subtypes 

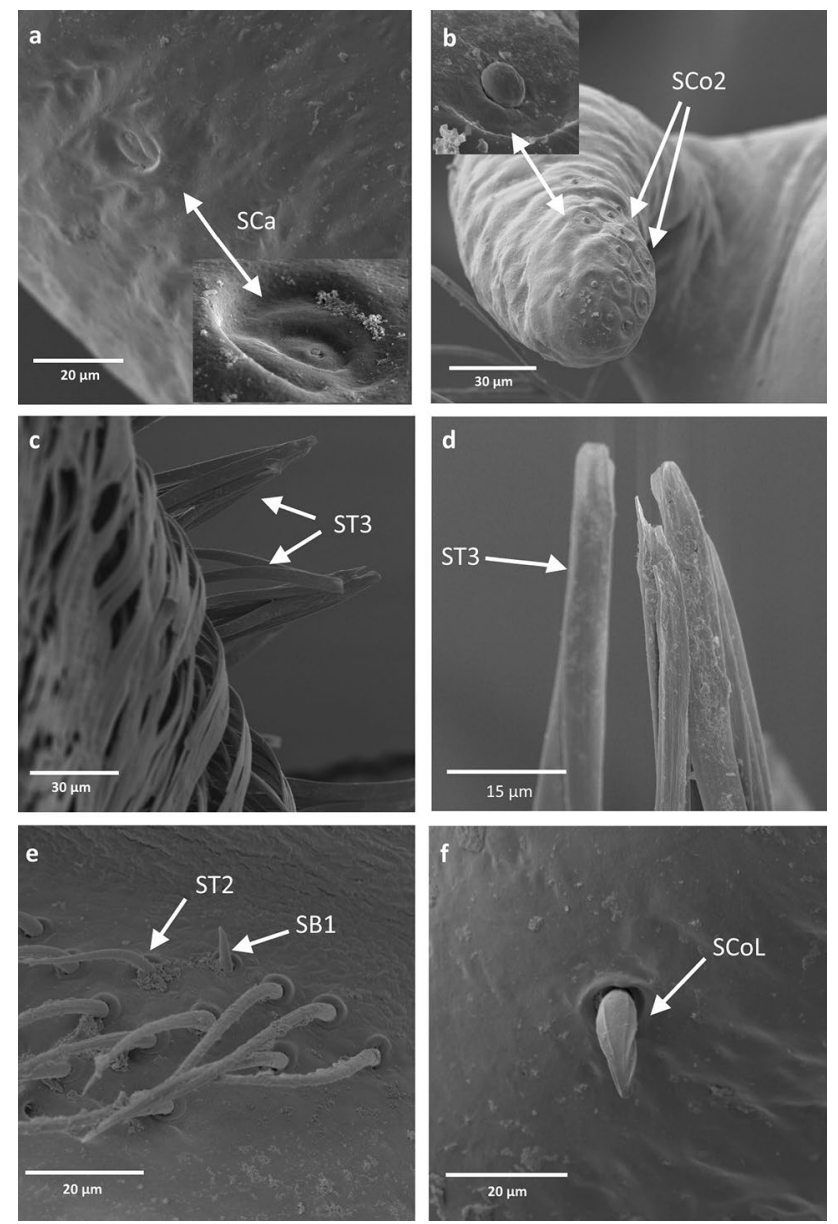

Fig. 6 Distribution of sensilla in Lethocerus indicus. SCa sensilla campaniformia, SCo2 sensilla coeloconica subtype 2, ST3 sensilla trichodea subtype 3, ST2 sensilla trichodea subtype 2, SB1 sensilla basiconica subtype 1, SCoL sensilla cone-like

of sensilla basiconica (SB2 and SB3) and three subtypes of sensilla coeloconica (SCo1, SCo2, SCo3) distinguished:

Sensilla basiconica (SB)—straight (SB2) or bent toward the antenna (SB3) cones with porous surface that rise from inflexible sockets. They are found on the second and third antennomere. On the second antennomere, they are usually organized in groups growing along with sensilla coeloconica. They are more sparsely distributed on the third antennomere and on the process of the second antennomere. Porous sensilla basiconica are common for the examined species (Figs. 3, 4f, 5c, 7b, c, 8c, 9d, e, 10a, 11a, d, 12b).

Sensilla coeloconica (SCo)- they are peg in pit sensilla, slightly embedded in shallow open cavities of the cuticle (SCo1) or growing over it (SCo2-occurring as small pegs, SCo3-visibly bigger pegs growing over the cuticle). They bear pores at the tip as long as on the whole surface and are embedded in inflexible sockets. Sensilla coeloconica are numerous and occur in groups on the antennal surface. A characteristic feature for the
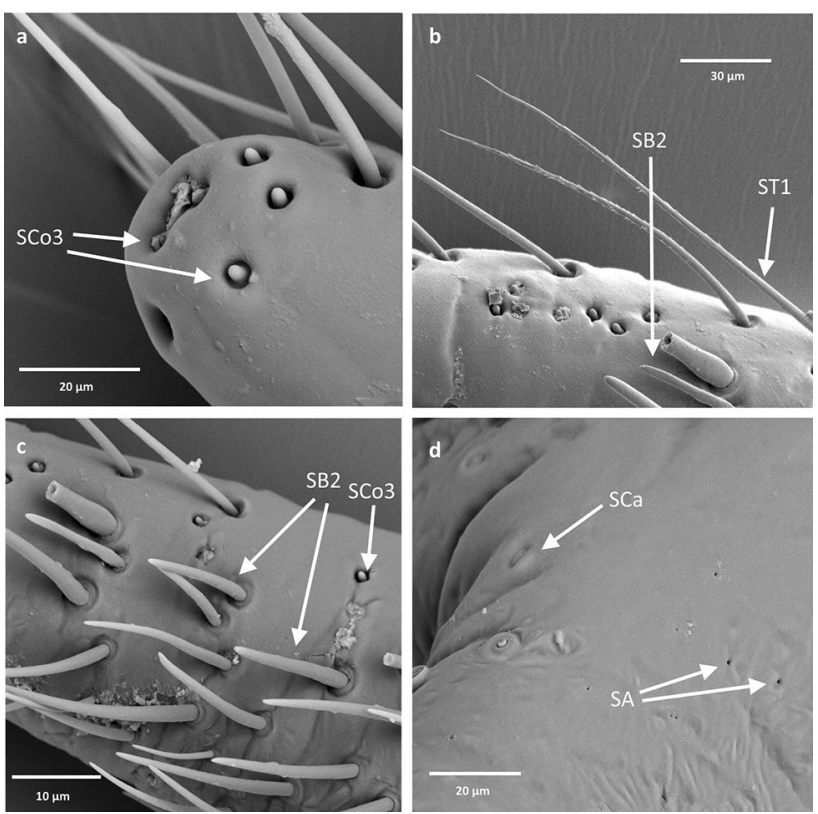

Fig. 7 Distribution of sensilla in Nepa cinerea. SCo3 sensilla coeloconica subtype 3, SB2 sensilla basiconica subtype 2, ST1 sensilla trichodea subtype $1, S C a$ sensilla campaniformia
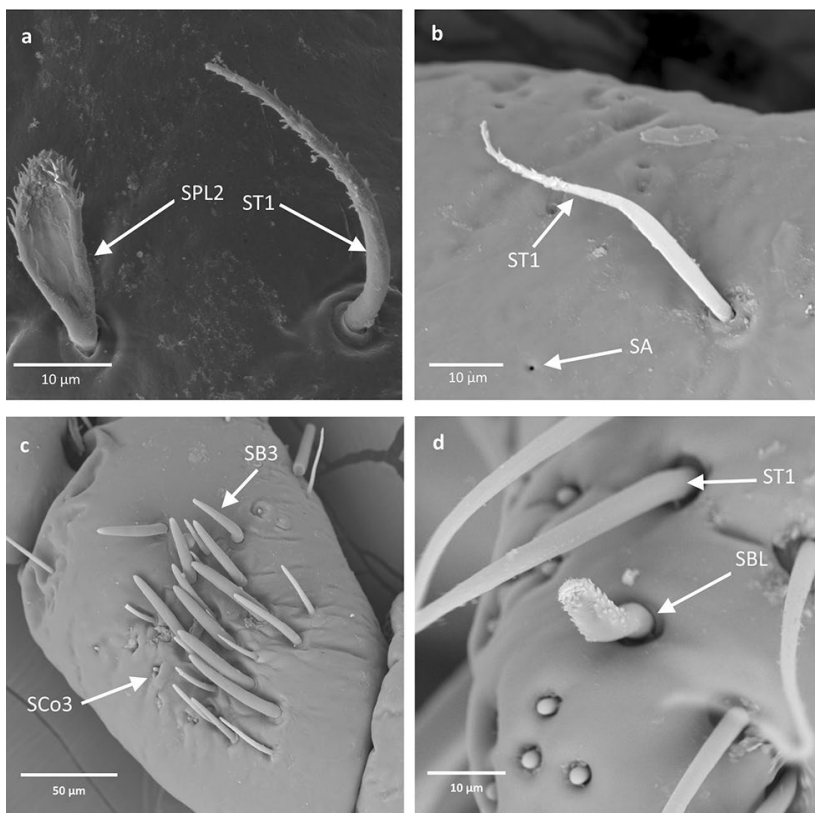

Fig. 8 Distribution of sensilla in Nepa cinerea. SPL2 sensilla paddlelike subtype 2, ST1 sensilla trichodea subtype 1, SA sensilla ampullacea, $S B 3$ sensilla basiconica subtype 3,SCo3 sensilla coeloconica subtype 3, $S B L$ sensilla brush-like

examined species was the occurrence of $\mathrm{SCo} 3$ at the tip of the antennae (Figs. 4c, 7a, 12c) and $\mathrm{SCo} 2$ on the process of the fourth antennomere in L. indicus and L. patruelis (Fig. 6a). Sensilla coeloconica were found in all the 

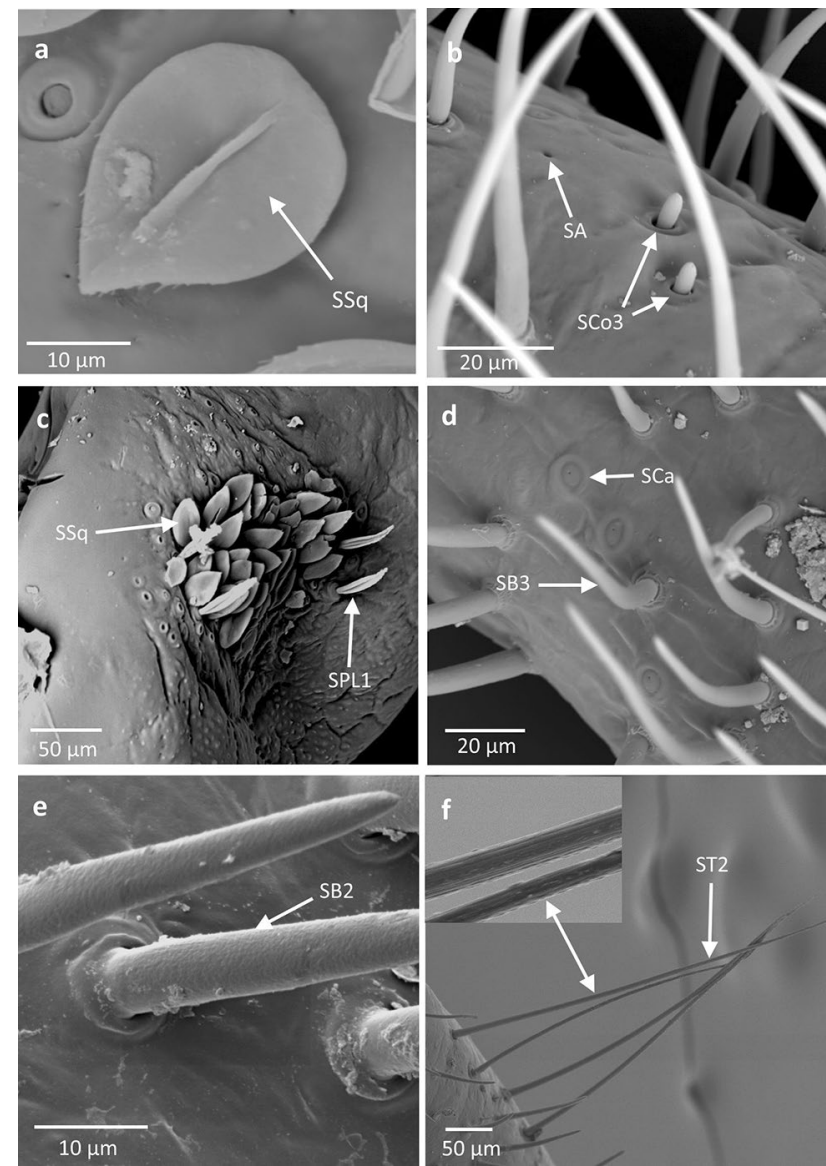

Fig. 9 Distribution of sensilla in Laccotrephes fabricii and Laccotrephes fuscus. a-c $L$. fabricii; $\mathbf{b}-\mathbf{f} L$. fuscus. $S S q$ sensilla squamiformia, $S A$ sensilla ampullacea, SCo3 sensilla coeloconica subtype 3, SPL1 sensilla paddle-like subtype $1, S C a$ sensilla campaniformia, $S B 3$ sensilla basiconica subtype $3, S B 2$ sensilla basiconica subtype 2, ST2 sensilla trichodea subtype 2

examined species (Figs. 3, 5b, 6b, 7a, c, 8c, 9b, 10d, 11c, $12 \mathrm{a}, \mathrm{c})$.

\section{Discussion}

This paper contains a detailed morphological study on the antennal sensilla of Nepoidea using scanning electron microscopy (SEM). In previous studies, the general morphology of antennae and the presence of sensilla (trichodea, chaetica and basiconica) have been reported by Popov (1971), Schuh and Slater (1995) and Chen et al. (2005). Moreover, scant data based on ultrastructural study of the sensilla of two species (Nepa cinerea and Ranatra linearis) have been presented by Chaika and Sinitsina (1999). The authors described sensilla chaetica and sensilla papillae in the mentioned species, with emphasis on their chemosensory function.
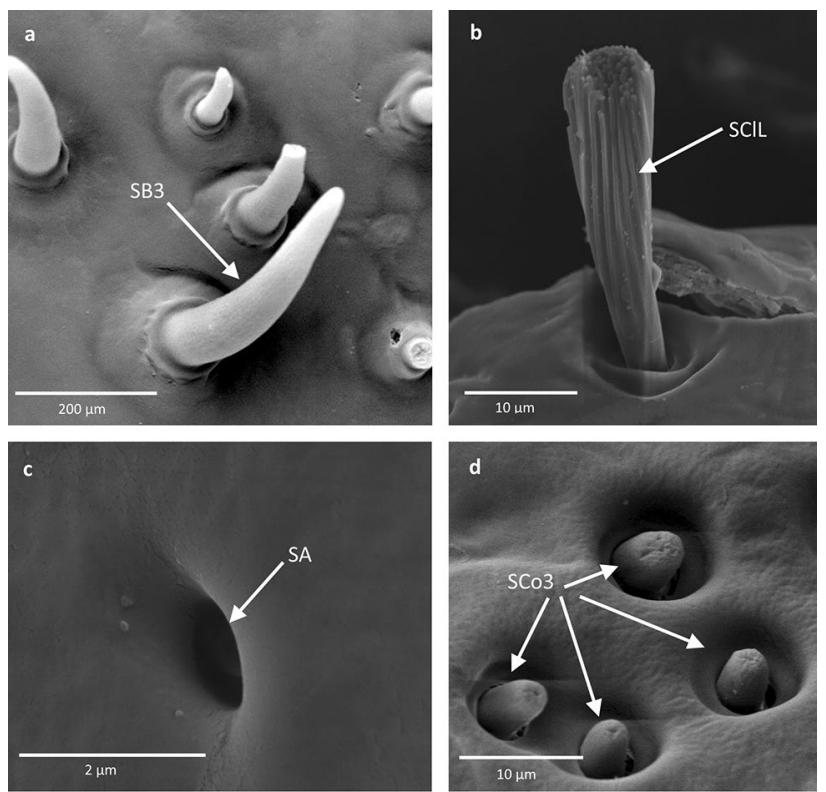

Fig. 10 Distribution of sensilla in Ranatra grandocula. SB3 sensilla basiconica, $S C l L$ sensilla club-like, $S A$ sensilla ampullacea, $S C o 3$ sensilla coeloconica subtype 3
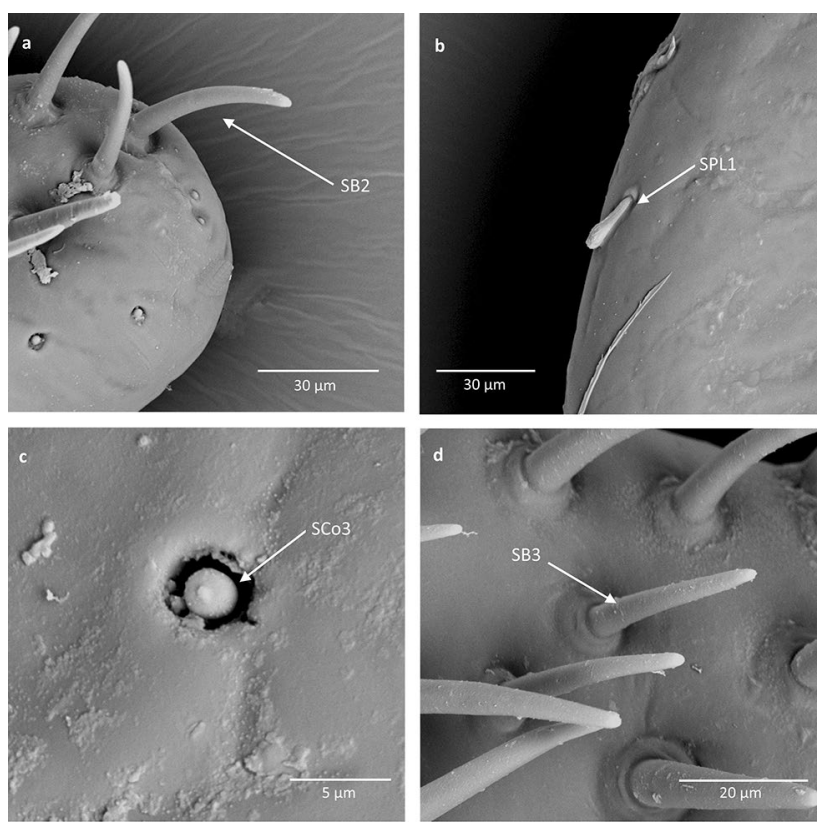

Fig. 11 Distribution of sensilla in Ranatra linearis. SB2 sensilla basiconica subtype 2, SB3 sensilla basiconica subtype 3, SPL1 sensilla paddle-like subtype $1, S C o 3$ sensilla coeloconica subtype 3

The antennal sensilla of Nepoidea are very interesting due to their water habitat. In this study, we focused essentially on the inventory of the antennal sensilla of several species belonging to this taxon. Also, we research whether the differences between families or species might have favored 

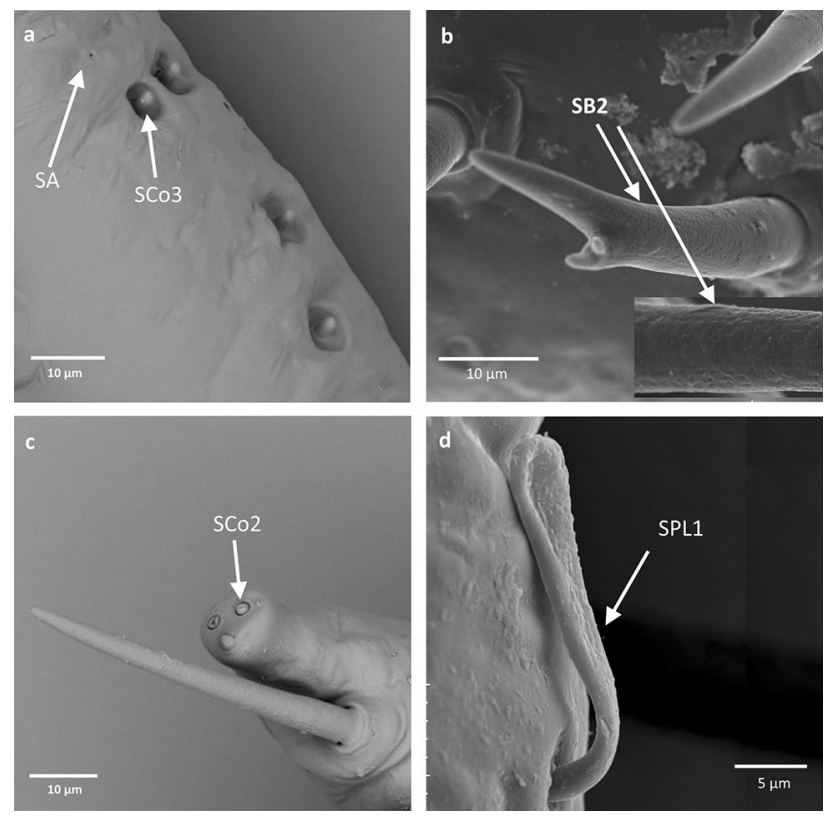

Fig. 12 Distribution of sensilla in $R$. unicolor. $S A$ sensilla ampullacea, $S B 2$ sensilla basiconica subtype 2, SCo2 sensilla coeloconica subtype 2, SPL1 sensilla paddle-like subtype 1

differences in the equipment within antennal sensilla. We discuss whether the complexity and importance of mechanical and chemical stimuli relevant for water species lead to the expectation of the number of sensilla types. We also investigate whether it leads to possibly higher or lower density on antennae, compared to the types of the sensilla in semi-aquatic and terrestrial heteropteran species.

\section{Sensilla types and function of Nepoidea}

Twelve morphological types of sensilla have been described and their probable functions have been indicated in the aquatic bugs examined during these studies.

The most conspicuous mechanosensillar characteristic in the Nepoidea species is the presence of $S$. trichodea and $S$. campaniformia, which seem to be typical for both families. These sensilla are more or less numerous in particular species. Sensilla campaniformia are present in all species. Sensilla trichodea were found to be more dominant in Belostomatinae and Lethocerinae than in Nepinae. In Ranatrinae, sensilla trichodea were absent. The other common type of mechanosensilla_-sensilla chaetica, present in many heteropteran insects (Chinta et al. 1997; Slu 1980; Akent' eva 2008; Ahmad et al. 2016; Nowińska and Brożek 2017), is poorly represented in Nepoidea. Less numerous sensilla chaetica were observed only in Belostomatidae $(H$. colombiae or L. patruelis). However, several other types of mechanosensilla, which are not common among heteropteran insects, were found in some species of these water bugs. A characteristic feature of these sensilla types is a sparse occurrence on the antenna. The sensillum cone-like (SCoL) is characteristic of Lethocerus. Other special sensilla, brush-like and club-like, were present in Nepa and Ranatra, respectively, whereas in Nepa and Laccotrephes a group of sensilla squamiformia was present on the first antennomere. Furthermore, some sensilla paddle-like were designated as mechanosensilla in species of Nepidae and Lethocerinae and they displayed morphological similarity (SPL1, SPL2) between these taxa. Strangely, due to the lack of sensilla trichodea and chaetica on the antennae of Ranatra, their singular paddle-like and club-like sensilla are probably mainly responsible for mechanosensillar signals.

Sensilla basiconica (SB1) represent also mechanosensilla. However, they probably occur in most of studied species. Due to their usual place of occurrence (between the antennomeres), it is possible that many of them are hidden.

Chemosensitive sensilla basiconica SB2, SB3 are well represented in all of the Nepoidea species. Due to their surface being mostly covered with wall pores, it seems that they are olfactory sensilla. We distinguished another type of chemosensilla - sensilla coeloconica, with three subtypes that also have an olfactory function. Modifications of the sensilla seem to be a part of insects' adaptation to the aquatic environment. Sensilla basiconica (SB3) tend to bend toward the main axis of the antenna, while usually all sensilla coeloconica are short and hidden, protecting themselves from mechanical interference. Based on the presented data, it seems that the olfactory system in Nepoidea is rather poor. Probably, it consists of few sensilla basiconica and a small group of sensilla coeloconica, although the sets of olfactory sensilla are different in some species. Only $H$. colombiae have been equipped with all types/subtypes of olfactory sensilla (SB2, SB3, SCo1 $\mathrm{SCo} 2, \mathrm{SCo} 3)$. In the remaining belostomatid species, the olfactory system consists of three types of less numerous sensilla (SB2, SB3, SCo3) (as in $B$. elegans and D. annulatus) and two types (SB2, SCo2) in $L$. indicus and L. patruelis. Similar differences in set and types of olfactory sensilla were estimated in Nepidae, where only one species L. fabricii had four types of sensilla (SB2, SB3, $\mathrm{SCo} 2, \mathrm{SCo} 3)$. However, the other species possessed two various sets of sensilla and they differed in the presence or lack of the two types of sensilla basiconica or coeloconica. In L. fuscus, $N$. cinerea and $R$. grandocula, the set of the olfactory sensilla, include two subtypes of sensilla basiconica and one subtype of sensillum coeloconicum (SB2, SB3, $\mathrm{SCo} 3$ ). The opposite set of sensilla (SB2, SCo2, SCo3) was distinguished in the next taxa, $R$. linearis and $R$. unicolor. However, the olfactory sensilla placodea that were observed in other insects and heteropteran bugs (Ahmad et al. 2016; Nowińska and Brożek 2017) do not occur in Nepoidea.

The presence of an olfactory system in some species of water bugs was previously pointed by Chaika and 
Sinitsina (1999) and the present data confirm it, based on the porous wall of sensilla basiconica and coeloconica in other water bug species. Terrestrial insects usually use their olfactory system to detect sexual pheromones as well as other olfactory stimuli. In nepomorphan species, however, because of their watery life, the sexual behavior of the species is realized by the signal/stridulatory system (Jansson 1973), so the olfactory sensilla are used only when the species are on the water surface or on land.

As for thermo-hygrosensilla, it turned out that numerous sensilla ampullacea occur almost in every species: B. elegans, $H$. colombiae, L. indicus, L. patruelis, $N$. cinerea, $L$. fabricii and $R$. grandocula. It seems that the thermo-hygrosensilla that were found on these taxa probably play a role in the location or identification of water reservoirs during settlement. This could explain the presence of thermo- hygroreceptors found on the antennae in these groups. According to Duviard (1974), relative humidity and temperature are limiting factors for flight of the belostomatid insects. Other studies also suggest that the presence of thermosensilla in water insects is due to their dispersal flight behavior (Song et al. 2017). Also, metathoracic scent glands, which are believed to be used to mark the trail to the egg clutch (Smith 1997), have been found in Belostomatidae. Therefore, it might be an explanation for the presence of olfactory chemosensilla on their antennae.

Nepidae live near the surface of water. When undisturbed, they keep contact with the atmosphere with the use of siphons. Only some Ranatrinae are able to settle in deeper water. They do not actively hunt, instead hiding in the mud or vegetation, waiting for prey. When prey comes, they grab it with the fore legs. Sensory organs, especially the apical ones on the fore tibiae, are believed to play a role in helping to locate potential prey (Hoffmann 1927, 1933; Chen et al. 2005). During this study, sensilla were found on the tip of the antennae $(\mathrm{SCo} 3)$ of many species. These are believed to be chemosensilla. We speculate that it may also help aquatic bugs with locating prey. The behavior of Belostomatidae is believed to deviate slightly from Nepidae when it comes to feeding habits. There are indications that Belostomatidae, besides hiding and waiting for prey, may actually be foraging (Smith 1997; Cloarec 1989a, b, 1991a, b, 1992; Chen et al. 2005), so the species need different types of chemosensilla to be able to recognize various chemical substances with their olfactory system. Because the antennal sensilla may be associated with chemical perception and different behavioral responses (Zacharuk 1980), the antennal chemosensilla (porous sensilla basiconica and coeloconica) in Nepoidea species are similar to the other terrestrial bug species.

\section{Differences between Nepoidea and other heteropteran groups}

One of the aims of our study was to confirm if the true water bugs have a lot in common with the semi-aquatic bugs when it comes to the character, types and distribution of antennal sensilla. Both groups are connected to water habitats. The difference is in how they adapt to them. Semi-aquatic bugs (Gerromorpha) live on the water surface, on aquatic plants or near water reservoirs (Andersen 1982), while Nepoidea prefer being submerged in water (Menke 1979). Another difference between these taxa lies in the length of their respective antennae-the antennae of Gerromorpha have been studied (Andersen 1982) and did not show a big difference between semi-aquatic bugs and terrestrial Heteroptera. The antennae are long and easily visible because they grow beyond the length of the head, similarly to terrestrial heteropterans (Nowińska and Brożek 2017). However, in Nepoidea the antennae are always difficult to see because they are concealed behind the eyes and bear additional processes on the antennomeres, unlike in Gerromorpha (Schuh and Slater 1995). Antennomeres of species of Belostomatidae (B. elegans, H. colombiae, L. indicus, L. patruelis) tend to curve toward the ventral side of the antenna. The processes on the second and third antennomeres (and the small process on the fourth antennomere in Lethocerus) are also curved. However, we did not observe any curving of antennomeres or processes in Nepidae. Moreover, in some of the species examined (B. elegans, Lethocerus, L. fuscus, $L$. fabricii, $R$. linearis, $R$. unicolor), the last antennomere is the longest and tends to bend across the main axis of antenna, resembling the process on the previous antennomere. However, other authors (Popov 1971; Schuh and Slater 1995) described this part as an antennomere in belostomatid and nepid species, and did not distinguish the processes' surface on this structure. We decided to describe it in the same way as the authors mentioned above (Popov 1971; Schuh and Slater 1995). In both Belostomatidae and Nepidae, most of the species studied had their antennae extending in width rather than length, with the processes extending across the general axis of the antenna. The antennae remain short but by extending in width, they extend the sensory surface. Besides the length of antennae, there is a visible difference in the density of sensilla. While in Gerromorpha all of the specimens examined had the antennae covered with sensilla trichodea (Nowińska and Brożek 2017), in Nepoidea only Lethocerinae and Nepinae had the sensilla surface covered with sensilla trichodea. Based on the images, it has been observed that in Lethocerinae there were more of these sensilla than in Nepinae. However, in Nepoidea, we discovered greater diversity in mechanosensilla in general. Nine main types of mechanosensilla have been found in Nepoidea, while only five have been found in Gerromorpha (Nowińska 
and Brożek 2017). Moreover, there are six main types of antennal sensilla pointed by several authors in Heteroptera. Those are sensilla trichodea, chaetica, campaniformia, coeloconica, basiconica and placodea (Catalá 1997; Gracco and Catalá 2000; Guerenstein and Guerin 2001; Carbajal de la Fuente and Catalá 2002; Slu 1980; Chinta et al. 1997; Rani and Madhavendra 2005; Ventura and Panizzi 2005; Rani and Madhavendra 1995; Brézot et al. 1997; Sinitsina and Chaika 1998; Ahmad et al. 2016; Akent'eva 2008; Nowińska and Brożek 2017). The antennae of Gerromorpha are considered to bear only three of these main sensilla types.

In Nepoidea, five main types of sensilla, present also in other Heteroptera, were found, except for sensilla placodea. Additionally, five new types of mechanosensilla have been discovered (sensilla cone-like, brush-like, club-like, paddlelike and squamiformia), not similar in shape to the sensilla present in terrestrial and semi-aquatic bugs.

The sensory organ in the antennae that has been already studied and is not considered in this examination is the Johnston's organ. It is located in the second antennal segment and its function is to receive stimuli from the movement at the joint between the second and third antennal segments. In Nepoidea, however, it is believed to be the least developed from all Nepomorpha (Hüfner 1939; Chen et al. 2005).

\section{Conclusions}

The antennae of Nepoidea essentially differ in shape and length from the antennae in Gerromorpha (despite the similar environment) and terrestrial bugs. The presence of the lateral processes on the antennomeres in this taxon increases the sensorial surface.

Generally, Nepoidea have less numbers of sensilla in comparison to other insects. However, essential basal types of sensilla constitute the entirety of their antennal sensory system. The characteristic feature of Nepoidea is a great morphological diversity when it comes to mechanosensilla. Nine types were recognized, five of which were new for this taxon. So far, such types of antennal sensilla have not been described in other heteropteran species. Each species tends to have only one type of thermo-hygrosensilla performing this function. Chemosensilla/olfactory were found in all the examined species and are believed to play specific roles in the behavior of the water bugs.

Acknowledgements The authors would like to thank H. Zettel from the Naturhistorisches Museum in Vienna, H. Enghoff from the Natural History Museum of Denmark in Copenhagen, P. Baňař from Moravian Museum in Brno and P. Kment from the National Museum in Prague for the access to their respective nepomorphan collections, and J. Karcz and M. Kanturski from the University of Silesia in Poland for SEM documentation in the Laboratory of Scanning Microscopy. This study was financed by sources for young scientists of the University of Silesia (rector grant)

\section{Compliance with ethical standards}

Ethical approval This article does not contain any studies with human participants performed by any of the authors.

Open Access This article is distributed under the terms of the Creative Commons Attribution 4.0 International License (http://creativeco mmons.org/licenses/by/4.0/), which permits unrestricted use, distribution, and reproduction in any medium, provided you give appropriate credit to the original author(s) and the source, provide a link to the Creative Commons license, and indicate if changes were made.

\section{References}

Ågren L (1978) Flagellar sensilla of two species of Andrena (Hymenoptera: Andrenidae). Int J Insect Morphol Embryol 7:73-79

Ahmad A, Parveena Sh, Brożek J, Dey D (2016) Antennal sensilla of phytophagous and predatory pentatomids (Hemiptera: Pentatomidae): a comparative study of four genera. Zool Anz 261:48-55

Akent'eva NA (2008) The formation of the antenna sensory apparatus in some bug (Heteroptera) species in the course of their postembryonic development. Entomol Rev 88:381-390

Altner H, Prillinger L (1980) Ultrastructure of Invertebrate ChemoThermo- and Hygroreceptors and Its Functional Significance. Int Rev Cytol 67:69-139

Andersen NM (1982) The semiaquatic bugs (Hemiptera, Gerromorpha) phylogeny, adaptations, biogeography and classification. Scandinavian Science Press Ltd, Klampenborg

Attygalle AB, Jham GN, Svatos A, Frighetto RT, Ferrara FA, Vilela EF, Uchoa-Fernandes MA, Meinwald J (1996) 3E,8Z,11Z)-3,8,11tetradecatrienyl acetate, major sex pheromone component of the tomato pest Scrobipalpuloides absoluta (Lepidoptera: Gelechiidae. Bioorg Med Chem 4:305-314

Backus EA (1985) Anatomical and sensory mechanisms of leafhopper and planthopper feeding behaviour. In: Nault LR, Rodriguez JG (eds) The leafhoppers and planthoppers. Wiley, New York, pp 163-194

Blaustein L (1998) Influence of the predatory backswimmer, Notonecta maculata, on invertebrate community structure. Ecol Entomol 23:246-252

Brézot P, Tauban D, Renou M (1997) Sense organs on the antennal flagellum of the green stink bug, Nezara viridula (L.) (Heteroptera: Pentatomidae): sensillum types and numerical growth during the post-embryonic development. Int J Insect Morphol Embryol 25:427-441

Brożek J (2013) Comparative analysis and systematic mapping of the labial sensilla in the Nepomorpha (Heteroptera: Insecta). Sci World J 2013:1-44

Brożek J (2014) Phylogenetic signals from nepomorpha (Insecta: Hemiptera:Heteroptera) mouthparts: stylets bundle, sense organs, and labial segments. Sci World J 2014:1-30

Brożek J, Bourgoin T (2013) Morphology and distribution of the external labial sensilla in Fulgoromorpha (Insecta: Hemiptera). Zoomorphology 133:33-65

Brożek J, Zettel H (2014) A comparison of the external morphology and functions of labial tip sensilla in semiaquatic bugs (Hemiptera: Heteroptera: Gerromorpha). Eur J Entomol 111(2):275-297 
Carbajal de la Fuente AL, Catalá SS (2002) Relationship between antennal sensilla pattern habitat in six species of Triatominae. Mem Inst Oswaldo Cruz 97:1121-1125

Catalá SS (1996) Sensilla associated with the rostrum of eight species of Triatominae. J Morphol 228:195-201

Catalá SS (1997) Antennal sensilla of Triatominae (Hemiptera, Reduviidae): a comparative study of five genera. Int J Insect Morphol Embryol 26(2):67-73

Chaika SY, Sinitsina EE (1999) Sensory organs of the labium and antennae in water bugs (Heteroptera). Entomologicheskoye obozreniye $78(1): 40-59$

Chapman RF (1998) Mechanoreception. Chemoreception. In: Chapman RF (ed) The insects, structure and function. Cambridge University Press, Cambridge, pp 610-652

Chen P-P, Nieser N, Zettel H (2005) The aquatic and semi-aquatic bugs (Heteroptera: Nepomorpha \& Gerromorpha) of Malesia. Fauna Malesiana Handbook 5. Leiden, Boston, pp 1-546

Chinta S, Dickens JC, Baker GT (1997) Morphology and distribution of antennal sensilla of the tarnished plant bug, Lygus lineolaris (Palisot de Beauvois) (Hemiptera: Miridae). Int J Insect Morph Embryol 26(1):21-26

Cloarec A (1989a) Variations of predatory tactics of a water bug during development. Ethology 86:33-46

Cloarec A (1989b) Variations of foraging tactics in water bug, Diplonychus indicus. J Ethol 7:27-34

Cloarec A (1991a) Handling time and multi-prey capture by a water bug. Anim Behav 42:607-613

Cloarec A (1991b) Predatory versatility in the water bud Diplonychus indicus. Behav Process 23:231-242

Cloarec A (1992) The influence of feeding on predatory tactics in water bug. Physiol Entomol 17:25-32

Cossé AA, Todd JL, Millar JG, Martínez LA, Baker TC (1995) Electroantennographic and coupled gas chromatographic-electroantennographic responses of the mediterranean fruit fly, Ceratitis capitata, to male produced volatiles and mango odor. J Chem Ecol 21:1823-1836

de Bruyne M, Baker TC (2008) Odor detection in insects: volatile codes. J Chem Ecol 34:882-897

Devetak D, Pabst MA, Lipovšek Delakorda S (2004) Leg chordotonal organs and campaniform sensilla in Chrysoperla Steinmann 1964 (Neuroptera): structure and function. Denisia 13:163-171

Drijfhout FP, Groot AT (2001) Close-range attraction in Lygocoris pabulinus (L.). J Chem Ecol 27:1133-1149

Duviard D (1974) Flight activity of Belostomatidae in central Ivory Coast. Oecologia 15:321-328

Esslen J, Kaissling KE (1976) Zahl und Verteilung antennaler Sensillen bei der Honigbiene (Apis mellifera L.). Zoomorphology 83:227-251

Gracco M, Catalá S (2000) Inter-specific developmental differences on the array of antennal chemoreceptors in four species of triatominae (Hemiptera, Reduviidae). Mem Inst Oswaldo Cruz 95:67-73

Guerenstein PG, Guerin PM (2001) Olfactory and behavioural responses of the blood-sucking bug Triatoma infestans to odours of vertebrate hosts. J Exp Biol 204:585-597

Guerenstein PG, Hildebrand JG (2008) Roles and effects of environmental carbon dioxide in insect life. Annu Rev Entomol 53:161-178

Hallberg E, Hansson BS (1999) Arthropod sensilla: morphology and phylogenetic consideration. Microsc Res Tech 47:428-439

Hebsgaard MB, Andersen NM, Damgaard J (2004) Phylogeny of the true water bugs (Nepomorpha: Hemiptera-Heteroptera) based on $16 \mathrm{~S}$ and 28S rDNA and morphology. Syst Entomol 29(4):488-508

Hoffmann WE (1927) Biological notes on Laccotrephes (Hemiptera, Nepidae). Lingnan Agric Rev 4:77-93

Hoffmann WE (1933) The life history of a second species of Laccotrephes (Hemiptera, Nepidae). Lingnan Sci J 12:245-257
Hüfner B (1939) Die Antennen und antennalen Sinnesorgane der Hydrocores mit besonderer Berücksichsichtigung der Nepiden. Zoologica 97:1-32

Inouchi J, Shibuya T, Matsuzaki O, Hatanaka T (1987) Distribution and fine structure of antennal olfactory sensilla in Japanese dung beetles, Geotrupes auratus Mtos. (Coleoptera: Geotrupidae) and Copris pecuarius Lew. (Coleoptera: Scarabaeidae). Int J Insect Morphol Embryol 16:177-187

Isidoro N, Bin F, Colazza S, Vinson SD (1996) Morphology of antennal gustatory sensilla and glands in some parasitoids Hymenoptera with hypothesis on their role in sex and host recognition. J Hym Res 5:206-239

Jansson A (1973) Stridulation and its significance in the genus Cenocorixa (Hemiptera, Corixidae). Behaviour 46:1-36

Jourdan H, Barbier R, Bernard J, Ferran A (1995) Antennal sensilla and sexual dimorphism of the adult ladybird beetle Semiadalia undecimnotata Schn. (Coleoptera: Coccinellidae). Int J Insect Morphol Embryol 24:307-322

Kanturski M, Ali Akbar S, Favret C (2016) Morphology and sensilla of the enigmatic Bhutan pine aphid Pseudessigella brachychaeta Hille Ris Lambers (Hemiptera: Aphididae)—a SEM study. Zool Anz 266(1):1-13

Keil TA (1999) Morphology and development of the peripheral olfactory organs. In: Hansson BS (ed) Insect olfaction. Springer, New York, pp 5-47

Kim JY, Leal WS (2000) Ultrastructure of pheromone detecting sensillum placodeum of the Japanese beetle, Popillia japonica Newman (Coleoptera: Scarabaeidae). Arthroprod Struct Dev 29:121-128

Martini R (1986) Fine structure and development of the large sensilla basiconica on the antennae of sphecid wasps. Tissue Cell Res 18:143-151

McIver SB (1975) Structure of cuticular mechanoreceptors of arthropods. Ann Rev Entomol 20(1):381-397

Menke AS (1979) The semiaquatic and aquatic Hemiptera of California (Heteroptera: Hemiptera). Bull Calif Insect Surv 21:70-86

Merivee E, Rahi M, Luik A (1999) Antennal sensilla of the click beetle, Melanotus villosus (Geoffroy) (Coleoptera: Elateridae). Int. J. Insect Morphol. Embryol 28:41-51

Nichols Z, Vogt RG (2008) The SNMP/CD36 gene family in Diptera, Hymenoptera and Coleoptera: Drosophila melanogaster, D. pseudoobscura, Anopheles gambiae, Aedes aegypti, Apis mellifera and Tribolium castaneum. Insect Biochem Mol Biol 38:398-415

Nieser N, De Coninck E, Chen PP (2010) Note on the taxonomy of the Laccotrephes fuscus (=L. brachialis) complex (Insecta: Heteroptera: Nepidae). J Afrotrop Zool 6:91-95

Nishida R, Schulz S, Kim CS, Fukami H, Kuwahara Y, Honda K, Hayashi N (1996) Male sex pheromone of a giant danaine butterfly, Idea leuconoe. J Chem Ecol 22:949-972

Nowińska A, Brożek J (2017) Morphological study of the antennal sensilla in Gerromorpha (Insecta: Hemiptera: Heteroptera). Zoomorphology 136:327-347

Paulmier I, Bagneres AG, Afonso CMM, Dusticier G, Riviere G, Clement JL (1999) Alkenes as a sexual pheromone in the alfalfa leafcutter bee Megachile rotundata. J Chem Ecol 25:471-490

Peregrine DJ (1972) Fine structure of sensilla basiconica on the labium of the cotton stainer, Dysdercus fasciatus (Signoret) (Heteroptera: Pyrrhocoridae). Int J Insect Morph Embryol 1(3):241-251

Popov YA (1971) Historical development of the hemipterous infraorder Nepomorpha. Trudy Paleontological Institute Academy of Science, USSR: Nauk, 129:1-228

Rani PU, Madhavendra SS (1995) Morphology and distribution of antennal sense organs and diversity of mouthpart structures in Odontopus nigricornis (Stall) and Nezara viridula L. (Hemiptera). Int J Insect Morphol Embryol 24(2):119-132 
Rani PU, Madhavendra SS (2005) External morphology of antennal and rostral sensillae in four hemipteran insects and their possible role in host plant selection. Int J Trop Insect Sci 25:198-207

Runck C, Blinn DW (1990) Population dynamics and secondary production by Ranatra montezuma (Heteroptera: Nepidae). J N Am Benthol Soc 9:262-270

Runck C, Blinn DW (1994) Role of Belostoma bakeri (Heteroptera) in the trophic ecology of a fishless desert spring. Limnol Oceanogr 39:1800-1812

Schuh RT, Slater JA (1995) True bugs of the world (Hemiptera: Heteroptera). Classification and natural history. Cornell University Press, New York, pp 111-116

Shields VDC (2010) High resolution ultrastructural investigation of insect sensory organs using field emission scanning electron microscopy. In: Mendez VA, Diaz J (eds) Microscopy: science, technology, applications and education. Formatex, Badajoz, pp 321-328

Sinitsina EE, Chaika SY (1998) The Antenna sensory apparatus of terrestrial bugs (Heteroptera). Zool Zh 77:1273-1284

Slifer EH (1970) The structure of arthropod chemoreceptors. Annu Rev Entomol 15:121-141

Slu C (1980) Ultrastructure of the antennal sensillae of the bug, Rhodnius prolixus (Hemiptera, Reduviidae). Parazitologiia 14:92-486

Smith RL (1997) Evolution of parental care in the giant water bugs (Heteroptera: Belostomatidae). In: Choe JC, Crespi BJ (eds) The evolution of social behavior in insects and arachnids. Cambridge University Press, Cambridge, pp 116-149

Song L-M, Wang X-M, Huang J-P, Zhu F, Jiang X, Zhang S-G, Ban L-P (2017) Ultrastructure and morphology of antennal sensilla of the adult diving beetle Cybister japonicus Sharp. PLoS One 12(3):e0174643. https://doi.org/10.1371/journal.pone.0174643

Štys P, Jansson A (1988) Check-list of recent family-group and genusgroup names of Nepomorpha (Heteroptera) of the world. Acta Entomologica Fennica 50:1-44 van Baaren J, Boivin G, Le Lannic J, Nenon JP (1999) Comparison of antennal sensilla of Anaphes victus and A. listronoti (Hymenoptera, Mymaridae), egg parasitoids of Curculionidae. Zoomorphology 119:1-8

Ventura MU, Panizzi AR (2005) Morphology of olfactory sensilla and its role in host plant recognition by Neomegalotomus parvus (Westwood) (Heteroptera: Alydidae). Braz Arch Biol Technol 48(4):589-597

Wang Y, Dai W (2017) Fine structure of mouthparts and feeding performance of Pyrrhocoris sibiricus Kuschakevich with remarks on the specialization of sensilla and stylets for seed feeding. PLoS One 12(5):e0177209. https://doi.org/10.1371/journal.pone.01772 09

Waters TF (1977) Secondary production in inland waters. Adv Ecol Res 10:91-164

Wcislo WT (1995) Sensilla numbers and antennal morphology of parasitic and non-parasitic bees (Hymenoptera: Apoidea). Int J Insect Morphol Embryol 24:63-81

Yarden G, Shani A, Leal WS (1996) (Z, E)-[alpha]- Farnesene-an electroantennogram-active component of maladera matrida volatiles. Bioorg Med Chem 4:283-287

Zacharuk RY (1980) Ultrastructure and function of insect chemosensilla. Annu Rev Entomol 25:27-47

Publisher's Note Springer Nature remains neutral with regard to jurisdictional claims in published maps and institutional affiliations. 